\title{
Identification of Delta-Aminolevulinic Acid Dehydratase (ALAD) Gene Polymorphism and Its Association with Anemia in Medical Study Programs and Doctor Profession 2012-2014 Syarif Hidayatullah State Islamic University
}

\author{
Moch Rizki Ramadhan, Chris Adhiyanto ${ }^{1}$, Zeti Harriyati ${ }^{2}$ \\ Molecular Biochemistry Department ${ }^{1}$, Medical Biology Department ${ }^{2}$ \\ Faculty of Medicine and Health Sciences \\ Syarif Hidayatullah State Islamic University \\ Jakarta, Indonesia \\ rizkiuin.8@gmail.com
}

\begin{abstract}
Delta-Aminolevulinic acid dehydratase (ALAD) is an enzyme that catalyzes the condensation of two mollecules Aminolevulinic acid (ALA) to form Monopyrrole phorpobilinogen (PBG) in the pathway for heme synthesis. ALAD gene polymorphism is important for Lead (Pb) metabolism in blood. Recent studies indicated that ALAD gene polymorphism may influence an individual's level of hemoglobin. The purpose of this research is to discover the existance of ALAD gene polymorphism and its association with anemia in Indonesian aldolescent subjects $(\mathrm{N}=102)$. All subjects was a medical student of Universitas Islam Negeri Syarif Hidayatullah Jakarta grade 2012-2014. The method was used Amplification Refractory Mutation System-PCR (ARMS-PCR). The result showed that 22 subjects $(21.6 \%)$ had ALAD-1, 71 $(69.6 \%)$ for ALAD-1/2, and $9(8.8 \%)$ for ALAD-2 genotype. The measurement of hemoglobin levels showed that 41 subjects (40.2\%) had normal hemoglobin level and 61 subjects $\mathbf{( 5 9 . 8 \% )}$ had anemia. Although the measurement of hemoglobin levels showed that anemia was founded with higher frequency in ALAD-1/2 subjects ( $\mathrm{N}=42)$, we found no significant association between ALAD gene polymorphism and anemia in this study ( $p$-value $=0.908)$. Further confirmation with a blood lead level measurement is needed.
\end{abstract}

Keywords-ALAD; Pb;ARMS-PCR; Anemia

\section{INTRODUCTION}

Metals are substances with high electrical conductivity that can cause health problems [1]. Lead $(\mathrm{Pb})$ is one kind of metal with high toxicity that founded in many industrial environment, foods, cigarettes, and drinking water [2,3]. The source of $\mathrm{Pb}$ was from fuel oil, paint, pipes, batteries, toys, and water faucets [4,5]. Ministry of Environment and Forestry of Indonesia reports that transportation emission was the biggest pollution (85\%) in Indonesia. Environmental Project Agency also reports that in a motor vehicle $25 \% \mathrm{~Pb}$ will settle in machine and $75 \%$ others will release and contaminate air as exhaust fumes [6]. Pb can enter human body by gastrointestinal, respiration, and directly through skin then circulating bloodstream [7].

The exposure of $\mathrm{Pb}$ can affect intellectual growth in neonates, child, and also adult cognitive function. Recent research shows that higher amount of $\mathrm{Pb}$ in human body associated with hypertension, reproduction disorder, and renal disfunction $[8,9]$. Every individual has the ability to control the metabolism of $\mathrm{Pb}$ with ALAD gene. ALAD is an enzyme that catalyzes second step of heme formation. ALAD converts 2 molecules of aminolevulinic acid to monopyrrole porphobilinogen [10]. Interaction between $\mathrm{Pb}$ and human body will bring up a genetic variation of ALAD [11]. A genetic variation in one population $(1 \%)$ or more called polymorphism $[12,13]$. ALAD coded by gene located in chromosome 9q34 and expressed in all body tissues, but larger in erythrocyte and liver [14]. ALAD polymorphism arises from transversion of $\mathrm{G}$ to $\mathrm{C}$ at base position 177. This transversion leads to the emergence of two alleles namely ALAD-1 and ALAD-2, and the emergence of three phenotypes of ALAD-1, ALAD-1/2, and ALAD-2. The ALAD-2 allele contains the substitution of the amino acid asparagine into lysine [15].

Epidemiological study in Europe, Asia, and America showed that proportion of ALAD polymorphism was different between populations [16]. Variations that occur in ALAD gene allow $\mathrm{Pb}$ metabolism disturbances in many people [17]. Pb compete with Zinc ( $\mathrm{Zn}$ ) on active site of ALAD enzyme so that interfere heme synthesis. $\mathrm{Pb}$ has strong bound $(90 \%)$ to hemoglobin, so the toxicity was higher too. A disturbance of heme synthesis can bring out microcytic hypochromic anemia. There are many etiologies cause 
microcytic hypochromic anemia such as thalassemia and iron deficiency anemia [7,17]. Because of the important role of the ALAD gene in the biological course of $\mathrm{Pb}$, it is necessary to identify the genetic polymorphism of ALAD so as to minimize the possibility of anemia and other diseases caused by the genetic polymorphism.

\section{METHODS}

\section{A. Study Design and Setting}

This research use descriptive analytic method with cross sectional design. This research was conducted from August 2015 to March 2016 at the Laboratory of Cell Culture, Faculty of Medicine and Health Sciences, Syarif Hidayatullah State Islamic University (UIN), and Biochemistry Laboratory, Faculty of Mathematics and Natural Sciences, Jakarta State University.

\section{B. Subjects}

Subjects in this study were male and female medical student of UIN Syarif Hidayatullah Jakarta grade 2012 2014. The selection of this study using simple random sampling. We exclude samples that have a history of previous chronic infections. Research subjects are first given information related benefits and side effects research. Information is given in writing and explanation verbally by the researcher. The subject of the study was also given a written consent sheet stating that the subject was willing to follow this research.

\section{Data Collection}

This study uses primary data from respondents who have filled the informed consent sheet. Respondent data were obtained by $\mathrm{Hb}$ level test using Easy Touch ${ }^{\circledR} \mathrm{CGHb}$ meter and venous puncture as much as $3 \mathrm{cc}$ blood. Then blood taken through the venous puncture is placed into an EDTA tube and labeled, then stored in a biomedical freezer with a temperature of $40^{\circ} \mathrm{C}$. In addition to blood sampling, in the informed consent also included columns of age and gender data.

\section{Primer Design}

The primers we use are modified from a study conducted by Yamashiro [18]. Primer consists of specific primers of $G$ and $\mathrm{C}$ alleles to identify the polymorphisms present in each sample.

\section{E. DNA Extraction and Genotyping}

The DNA was extracted from a blood sample using the Genomic DNA Mini Kit (Blood/Cultured Cell) Geneaid GB100 [19]. Genetic polymorphism of ALAD was obtained from the genome amplification process by ARMS-PCR (Amplification Refractory Mutation System - Polymerase Chain Reaction) consisting of 2 stages of PCR.
PCR Stage 1 aims to amplify ALAD gene fragments, using primary and reverse primer compositions. PCR Stage 2 aims to identify ALAD gene polymorphisms, using both normal and mutant primers. Normal and mutant primers are used for each sample, so that every one sample will be interpreted with two lanes of electrophoresis gel. The target of PCR Stage 1 is the discovery of $306 \mathrm{bp}$ band and the target of PCR Stage 2 result is the finding of band along $168 \mathrm{bp}$ in electrophoresis result [18]. (Fig. 1)

\section{F. Electrophoresis and Gel Document System}

Electrophoresis in this study was used to interpret the results of genomic DNA isolation and analyze the results of PCR stage 1 and stage 2. The result of PCR Stage 2 was demonstrated by the discovery of $168 \mathrm{bp}$ band. If the tape is found on both normal and mutant lanes, it can be concluded that the sample has a heterozygot GC genotype (ALAD-1/2). If the tape is found on a normal course, it can be concluded that the sample has homozygot GG genotype (ALAD-1). Furthermore, if the tape is found in the mutant course, it can be concluded that the sample has a homozygot $\mathrm{CC}$ genotype (ALAD-2).

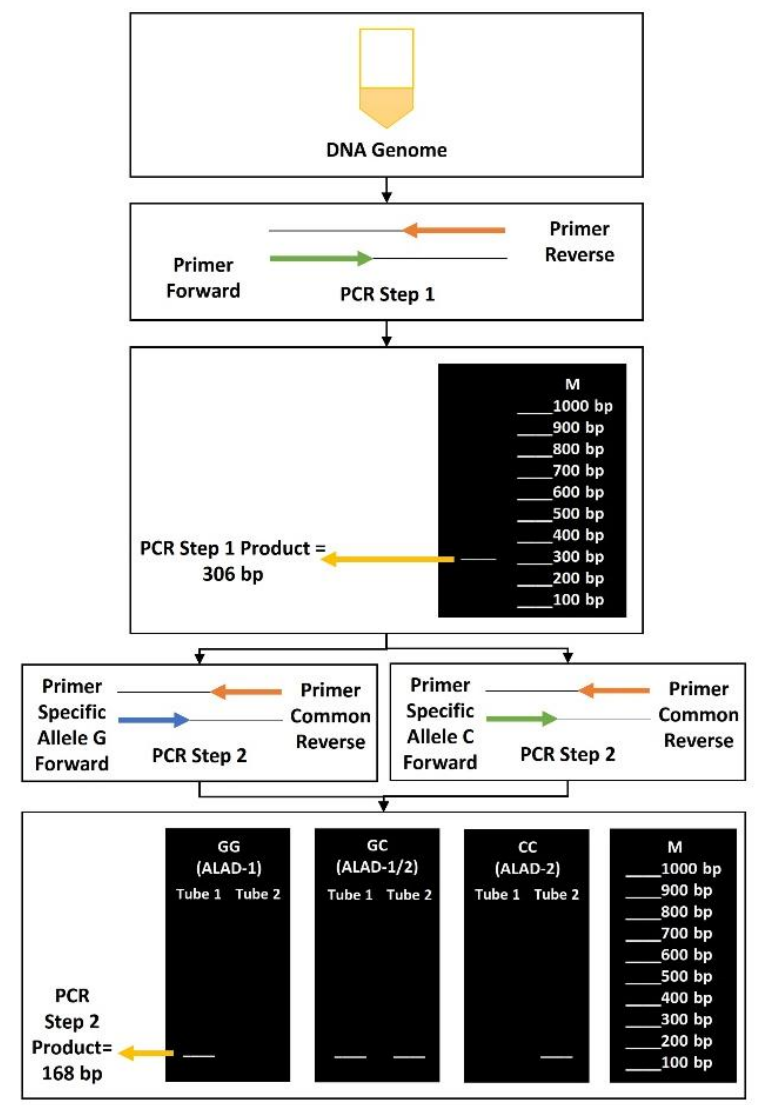

Fig. 1. Steps for identification of genetic polymorphism of ALAD with ARMS-PCR and electrophoresis. 


\section{G. Data Analysis}

Data were analyzed using IBM SPSS Statistics 22 software with chi-square test to find the relationship between anemia incidence with ALAD genetic polymorphism [20].

\section{H. Ethical Clearance}

This study has passed the ethical review of the Ethics Assessment Team of the Faculty of Medicine and Health Sciences UIN Syarif Hidayatullah Jakarta.

\section{A. Subjects and Data Collection}

The population of medical student of UIN Syarif Hidayatullah Jakarta grade 2012 - 2014 is 300 students. The number of respondents who are willing and in accordance with the criteria of this study are 102 students consisting of $37(36.3 \%)$ male students and $65(63.7 \%)$ female students. Age of respondents ranged between the ages of 18 to 23 years.

Results of hemoglobin examination found that from 102 samples there were $41(40.2 \%)$ samples with normal $\mathrm{Hb}$ and 61 (59.8) samples with $\mathrm{Hb}$ anemia. Grouping of hemoglobin levels based on normal $\mathrm{Hb}$ criteria from the Ministry of Health of Indonesia (normal $\mathrm{Hb}$ male $\geq 13 \mathrm{~g} / \mathrm{dL}$ and female $\geq 12 \mathrm{~g} / \mathrm{dL}$ ) [21]. (Table I).

TABLE 1. ALAD POLYMORPHISM AND SAMPLE CHARACTERISTICS.

\begin{tabular}{|c|c|c|c|c|}
\hline $\begin{array}{c}\text { Sample } \\
\text { Characteristics }\end{array}$ & $\mathbf{N}$ & $(\%)$ & Mean & $95 \% \mathrm{CI}$ \\
\hline Sex & & & 1.64 & $1.54-1.73$ \\
\hline Male & 37 & 36.3 & & \\
\hline Female & 65 & 63.7 & & \\
\hline Age (years) & & & 19.49 & $19.25-19.73$ \\
\hline 18 & 27 & 26.5 & & \\
\hline 19 & 23 & 22.5 & & \\
\hline 20 & 33 & 32.4 & & \\
\hline 21 & 16 & 15.7 & & \\
\hline 23 & 3 & 2.9 & & \\
\hline Hb Criteria ${ }^{[21]}$ & & & 1.60 & $1.50-1.69$ \\
\hline Normal & 41 & 40.2 & & \\
\hline Anemia & 61 & 59.8 & & \\
\hline $\begin{array}{c}\text { ALAD } \\
\text { Polymorphism } \\
\end{array}$ & $\mathbf{N}$ & $(\%)$ & Mean & $95 \%$ CI \\
\hline Genotype & & & 1.87 & $1.77-1.98$ \\
\hline ALAD-1 & 22 & 21.6 & & \\
\hline ALAD-1/2 & 71 & 69.6 & & \\
\hline ALAD-2 & 9 & 8.8 & & \\
\hline
\end{tabular}

\section{B. ALAD Gene Polymorphism}

The identification of ALAD gene polymorphism in this study used ARMS-PCR method. The result of PCR Phase 1 is shown in Figure 2. In this study all samples $(n=102)$ found the bands along $306 \mathrm{bp}$. Results of PCR Stage 2 showed that of 102 samples there were $22(21.6 \%)$ samples with GG genotype, $71(69.6 \%)$ samples had GC genotype, and 9 (8.8\%) samples had CC genotype.

The proportion of ALAD polymorphisms in the sample by sex shows that the GC genotype has the highest proportion of male and female samples with 25 male samples $(24.5 \%)$ having GC genotype and 46 female samples (45\%) having GC genotype. While the $\mathrm{CC}$ genotype has the lowest proportion with 2 men $(1.9 \%)$ and 7 women (6.8\%). Furthermore, 10 men $(9.8 \%)$ had GG genotype and 12 women $(11.7 \%)$ had GG genotype. (Table I).

\section{DISCUSSION}

In this study it was found that ALAD-1 genetic samples were $21.6 \%$, genetic ALAD-1/2 was $69.6 \%$, and ALAD-2 was $8.8 \%$. This is consistent with epidemiological studies conducted in Europe, Asia, and America suggesting that the highest genotype of ALAD-2 is found in Caucasian races with ALAD-1/2 proportions of only $18 \%$ and ALAD-1 reaching only $1 \%$ of the total population. In contrast, in African and Asian racial populations few subjects were found with ALAD-2 genotype [16,22,23]. ALAD polymorphism produces 3 different phenotypes: ALAD-1, ALAD-1/2, and ALAD-2. These three phenotypes have the same function, but have different electron charges. Asparagine is a neutral amino acid, while Lysine is a more positively charged amino acid. Therefore, the ALAD-1/2 gene (heterozygote) produces a higher enzyme electronegativity than ALAD-1 (homozygote), in addition ALAD-2 (homozygote) produces more electronegative enzymes compared to ALAD-1/2 [15]. Subjects with ALAD-1/2 and ALAD-2 genotypes had a higher susceptibility to elevated $\mathrm{Pb}$ levels in the blood than subjects with ALAD-1 genotype [24]. This is because $\mathrm{Pb}$ will be stronger bound to ALAD that has a high electronegative charge. A strong bond causes $\mathrm{Pb}$ to last longer in the blood, so the $\mathrm{Pb}$ toxic effect will be more severe. When $\mathrm{Pb}$ binds ALAD and inhibits its activity, subjects with the ALAD-2 genotype are better at compensating $\mathrm{Pb}$ than ALAD-1. This is more pronounced in populations with high and prolonged $\mathrm{Pb}$ exposure. When $\mathrm{Pb}$ binds to the active site of the ALAD enzyme, ALAD will respond by increasing its production. In the presence of such compensatory mechanisms, in populations with high and long $\mathrm{Pb}$ exposure there will be inhibition of lighter heme synthesis compared to subjects with ALAD-1 genotype. 


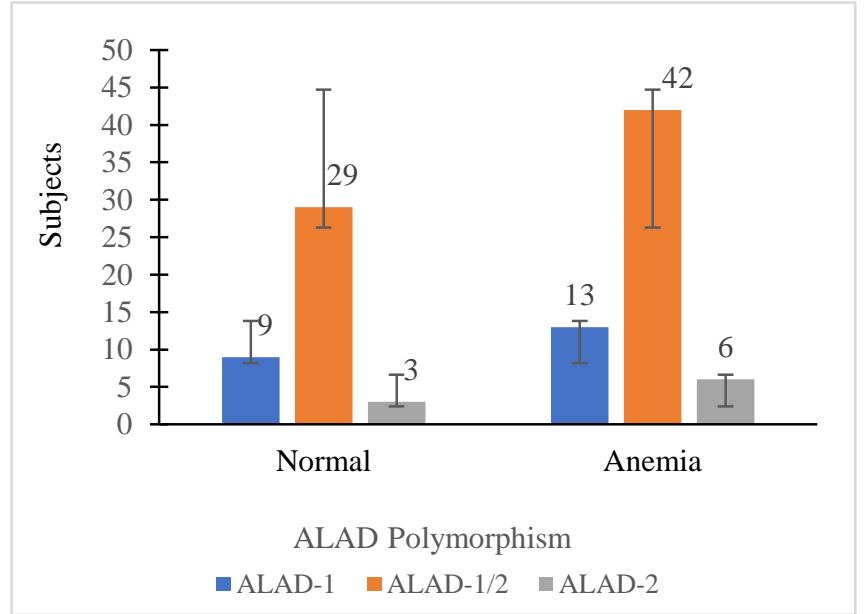

Fig. 2. Association Between ALAD Polymorphism with Anemia

We can see that levels of ALAD are inhibited by $\mathrm{Pb}$ toxic activity proportional to ALA (aminolevulinic acid) levels not processed in the cell cytoplasm. So it can be concluded that the less active ALAD enzyme, the more levels of ALA circulating in the cytoplasm. ALA is an acid that is toxic to the body $[15,16,24]$.

ALAD is an enzyme that is very important for the body so that if this enzyme does not work will cause the emergence of clinical manifestations are quite heavy for the body. ALAD is the second enzyme in the path of heme synthesis. This enzyme catalyzes the condensation of 2 ALA molecules to form 1 molecule of PBG (phorphobilinogen). ALAD is an enzyme located in the cytoplasm. ALAD enzyme is a tetramer homodimer enzyme that has 8 subunits that are identical with 1 active site in each dimer. This enzyme binds 8 zinc atoms in each of its subunits, 4 zinc molecules serve as a catalyst and the remaining 4 molecules act as tertiary structural stabilizers of the ALAD enzyme. Each active site will bind 2 ALA molecules in 2 different positions. One ALA molecule contributes as a side of acetic acid and an aminomethyl group of PBG, whereas one other ALA molecule contributes as a side chain of propionate and nitrogen pyrrole. $\mathrm{Pb}$ inhibits ALAD enzyme activity by replacing the zinc atomic position of the active site of the ALAD enzyme. So that ALAD enzyme activity will be disturbed. As a result, there is a build up of ALA in the blood plasma [14].

Disturbed heme formation may lead to hypochromic microcytic anemia. This is related to the inhibition of ALAD activity by $\mathrm{Pb}$. The etiology of anemia due to $\mathrm{Pb}$ exposure is less than that of iron deficiency anemia. However, the picture of iron deficiency anemia is similar to anemia due to $\mathrm{Pb}$ exposure $[25,26]$. In addition thalassemia also provides the same picture of hypochromic microcytic anemia $[10,29,30]$. With the various etiologies of the hypochromic microcytic anemia, we can conclude that the treatment of hypochromic microcytic anemia should be adjusted to its etiology. For example, in the case of hypochromic microcytic anemia with iron deficiency etiology necessarily requires treatment of iron supplements, but in contrast to hypochromic microcytic anemia with a $\mathrm{Pb}$ poisoning etiology that does not require iron supplements. If treatment is not in accordance with its etiology can cause serious complications [27,28]. Iron supplementation in anemic patients not due to iron deficiency leads to another disease called iron overload [31,32].

It is known that in ALAD-1 genotype, there are 9 people $(8.8 \%)$ who enter the criteria of normal $\mathrm{Hb}$ levels, and there are 13 people $(12.7 \%)$ who fall into the criteria of anemia. Then in the ALAD-1/2 genotype there were 29 people (28.4\%) who entered the criteria of normal $\mathrm{Hb}$ levels, and there were 42 people $(41.2 \%)$ who entered the criteria of anemia. Furthermore, in the ALAD-2 genotype, there were 3 people $(2.9 \%)$ who had normal $\mathrm{Hb}$ levels, and 6 people (5.8\%) were included in the criteria for anemia. (Fig. 2). It is known previously that ALAD is an enzyme that plays an important role in the heme synthesis process, thus identifying the association of ALAD genetic polymorphisms with important $\mathrm{Hb}$ levels to support the patient's diagnosis. From the Chi-Square test results, the expected value $<5$ is $16.7 \%$ (below 20\%), so the significance value of Pearson ChiSquare can be used [33,34]. The significance value obtained is 0.908 (p-value > 0.05). So it can be concluded that there is no significant relationship between ALAD genetic polymorphism with the incidence of anemia.

The absence of a significant association between ALAD genetic polymorphism data and the occurrence of anemia can indicate the existence of adaptation mechanisms of the body to environmental changes, especially those caused by $\mathrm{Pb}$. Individuals with ALAD-2 genotype have stronger $\mathrm{Pb}$ binding ability so that $\mathrm{Pb}$ remains attached to the active cycle of ALAD enzymes. This condition affects the process of subsequent $\mathrm{Pb}$ inhibition of the ferrochelatase enzyme. Thus, individuals with the ALAD-2 genotype have better ability to use iron $(\mathrm{Fe})$ ions in $\mathrm{Hb}$ synthesis. Unlike the case for individuals with ALAD-1 genotypes that have a weaker $\mathrm{Pb}$ bond, so $\mathrm{Pb}$ that enters the body will inhibit the action of the ferrochelatase enzyme $[35,36]$. Therefore it is necessary to check blood levels of $\mathrm{Pb}$ in the next study.

This study has the following limitations: First, there is no measurement of other diagnostic criteria for determining anemia and non-anemia such as peripheral blood smear examination, and erythrocyte haematological examination. Second, not looking for $\mathrm{Pb}$ serum data and $\mathrm{Pb}$ exposure data on respondents to know the relationship of $\mathrm{Pb}$ exposure to $\mathrm{Hb}$ criteria criteria (anemia and non-anemia). Third, not looking for data on menstrual status in female respondents to determine the possibility of other causes of anemia. 


\section{CONCLUSION}

We found the genetic polymorphism of ALAD with the highest proportion being ALAD-1/2 genotype (71 people from 102 samples, 69.6\%). There is no significant relationship between ALAD gene polymorphism and the incidence of anemia in this population ( $p$-value $=0.908$ ).

\section{CONFLICT OF INTEREST}

The authors have no conflict of interest

\section{ACKNOWLEDGEMENT}

This research is part of research collaboration with Faculty of Mathematics and Natural Sciences State University of Jakarta titled Hemoglobinopathy and Genetics. We are also grateful to all the research subjects who are willing to follow this research.

\section{REFERENCES}

[1] Tchounwou PB, Yedjou CG, Patlolla AK, Sutton DJ. Heavy metals toxicity and the environment. EXS. 2012;101:133-64.

[2] World Health Organization. Lead in drinking water : Background Document for Development of WHO Guidelines for Drinking-water Quality. WHO/SDE/WSH/03.04/09/Rev/1. 2011.

[3] Naja GM, Volesky B. Toxicity and sources of $\mathrm{Pb}, \mathrm{Cd}, \mathrm{Hg}, \mathrm{Cr}$, As, and radionuclides in the environment. In: Heavy Metals in The Environment; 2009. Page. 13-58.

[4] Jaishankar M, Tseten T, Anbalagan N, Matthew B, Beeregowda KN. Toxicity, mechanism and health effects of some heavy metals. Interdiscip Toxicol. 2014;7:60-72.

[5] Suherni. Keracunan timbal di Indonesia. 2010 Sept 16 [accessed on August 23, 2016]. Available at www.lead.org.au

[6] Gusnita D. Pencemaran logam berat timbal $(\mathrm{Pb})$ di udara dan upaya penghapusan bensin bertimbal. LAPAN. 2010:1-7.

[7] Santi DN. Pencemaran udara oleh timbal $(\mathrm{Pb})$ serta penanggulangannya. USU Digital Library. 2001:1-6.

[8] Warrington NM, Zhu G, Dy V, Heath AC, Madden PAF, Hemani G, et.al. Genome-wide association study of blood lead shows multiple associations near ALAD. Hum Mol Genet. 2015;13:3871-9.

[9] Deena T, Ananya R, Howard H, Bharmar M, Rama M, Kavitha P, et.al. IQ and blood lead levels: Effect Modification by ALAD Amongst Children in Chennai, India. Epidemiology. 2011;22:31-171.

[10] Sakamoto D, Kudo H, Inohaya K, Yokoi H, Narita T, Naruse K, et.al. A mutation in the gene for $\square$-aminolevulinic acid dehydratase (ALAD) causes hypochromic anemia in the medaka, Oryzas latipes. Mech Dev. 2004;121:747-52.

[11] Karki R, Pandya D, Elston RC, Ferlini C. Defining mutation and polymorphism in the era of personal genomics. BMC Med Genom. 2015;8:37.

[12] Huijun Z. Delta amino levulinic acid dehydratase (ALAD) polymorphism and its effect on human susceptibility to renal toxicity by inorganic lead [thesis]. [Lower Kent Ridge Rd]: National University of Singapore; 2005.

[13] van Bemmel DM, Li Y, McLean J, Chang MH, Dowling NF, Graubard $\mathrm{B}$, et.al. Blood lead levels, ALAD gene polymorphisms, and mortality. Epidemiology. 2011;22:273-8.

[14] Ajioka RS, Philips JD, Kushner JP. Biosynthesis of heme in mammals. Biochemica et Biophysica Acta. 2006;1763:723-36.

[15] Yang Y, Wu J, Sun P. Effects of delta-aminolevulinic acid dehydratase polymorphisms on susceptibility to lead in Han subjects from southwestern China. Int J Environ Res Public Health. 2012;9:2326-38.

[16] Kelada SN, Shelton E, Kaufmann RB, Khoury MJ. $\square$-Aminolevulinic acid dehydratase genotype and lead toxicity: A HuGE Review. Am J Epidemiol. 2001;154:1-13.

[17] van Bemmel DM, Boffetta P, Liao LM, Berndt SI, Menashe I, Meredith $\mathrm{Y}$, et.al. Comprehensive analysis of 5-aminolevulinic acid dehydrogenase $(A L A D)$ variants and renal cell carcinoma risk among individuals exposed to lead. PLoS ONE. 2011;6:1-7.

[18] Yamashiro Y, Hattori Y, Ferania M, Kentaro M. Delta-aminolevulinic acid dehydratase $(A L A D)$ gene amplification by PCR and amplification-refractory mutation system (ARMS). Presented at UNJ Workshop of Molecular Genetics, Universitas Negeri Jakarta, Jakarta. March 25, 2014.

[19] Geneaid. Blood/ cell DNA mini kit (GB100/GB300). 2017 Feb 10 [accessed on June 30, 2017]. Available at http://www.geneaid.com/products/genomic-dna-purification/dnaextraction-kit-blood-cultured-cell-miniprep.

[20] Almquist, Ashir, Branstorm. A guide to quantitative methods. Version 1.0. 2014 March 17 [accessed on October 27, 2017]

[21] Kementrian Kesehatan Republik Indonesia. Pedoman interpretasi data klinik. Jakarta; 2011. page. 8-27.

[22] Onalaja AO, Claudio L. Genetic susceptibility to lead poisoning. Environ Health Perpect. 2000;108:23-8.

[23] Shaik AP, Sultana SA, Alsaeed AH. Lead exposure: A Summary of Global Studies and The Need for New Studies from Saudi Arabia. Hindawi Journal. 2014.

[24] Miyaki K, Lwin H, Masaki K, Song Y, Takahashi Y, Muramatsu M, et.al. Association between a polymorphism of aminolevulinate dehydrogenase (ALAD) gene and blood lead levels in Japanese subjects. Int J Environ Res Public Health. 2009;6:999-1009.

[25] Ghosh A, Ghartimagar D, Thapa S, Sathian B, De A. Microcytic hypochromic anemia in pedriatic age group: A Hospital Based Study in Nepal. Am J Pub Heal Res. 2015;3:57-61.

[26] Zareifar S, Mazloomi S, Zahmatkeshan M, Shariari M, Najeeb KS, Fattah F. The association between blood lead level and microcytic hypochromic anemia in children. Inj J School Health. 2016;4:1-6.

[27] Fontana V, Baldi R, Franchini M, Gridelli P, Neri R, Palmieri F, et.al. Adverse haematological outcome and environmental lead poisoning. J Expo Anal Environ Epidemiol. 2004;14:188-93.

[28] US. Departement of Health and Human Services. NTP monograph on health effects of low-level lead. 2012.

[29] Hoffbrand AV, Moss PAH. Essential haematology. $6^{\text {th }}$ Edition. Oxford: Wiley-Blackwell; 2011. Page. 1-47.

[30] Lambert JF, Beris P. Pathophysiology and differential diagnosis of anaemia: Chapter 4. In : The Handbook Disorders of Erythropoiesis, Erythrocytes, and Iron Metabolism. Pagina; 2009. page. 108-141.

[31] Souza RM, Freitas LAR, Lyra AC, Moraes CF, Braga EL, Lyra LGC. Effect of iron overload on the severity of liver histologic alterations and on the response to interferon and ribavirin theraphy of patients with hepatitis C infection. Braz J Med Biol Res. 2006;39:79-83.

[32] Siddique A, Kowdley KV. Review Article: The iron overload syndromes. Aliment Pharmacol Ther. 2012;35:876-93.

[33] Tantur S. Research Guidance for Thesis in Medical Students (Panduan penelitian untuk skripsi kedokteran \& kesehatan). Jakarta; 2017. page. $102-5$.

[34] Field A. Correlation. In: Discovering Statistics Using SPSS. $3^{\text {rd }}$ Edition. California: SAGE; 2009. Page. 166-79.

[35] Chiu YW, Liu TY, Chuang HY. The effects of lead exposure on the activities of $\square$-aminolevulinic acid dehydratase with the modification of the relative genotypes. EDP Sciences. 2013;1;1-3.

[36] Scinicariello F, Yesupriya A, Chang M, Fowler BA. Modification by $A L A D$ of the association between blood lead and blood pressure in the U.S. population: Results from The Third National Health and Nutrition Examination Survey. Environ Health Perspect. 2010;118:259-64. 